\title{
Redescription, distribution and status of the Karwar Large Burrowing Spider Thrigmopoeus truculentus Pocock, 1899 (Araneae: Theraphosidae), a Western Ghats endemic ground mygalomorph
}

\author{
Manju Siliwal ${ }^{1} \&$ Sanjay Molur ${ }^{2}$ \\ ${ }^{1,2}$ Wildlife Information Liaison Development Society/ ${ }^{2}$ Zoo Outreach Organisation \\ 9-A, Lal Bahadur Colony, Peelamedu, Coimbatore, Tamil Nadu 641004, India \\ Email: manju@zooreach.org ${ }^{1}$; herpinvert@gmail.com²
}

Date of online publication 26 June 2009 ISSN 0974-7907 (online) | 0974-7893 (print)

Editor: Robert Raven

\section{Manuscript details:}

Ms \# 01733

Received 08 March 2007

Final received 01 June 2009

Finally accepted 16 June 2009

Citation: Siliwal, M. \& S. Molur (2009). Redescription, distribution and status of the Karwar Large Burrowing Spider Thrigmopoeus truculentus Pocock, 1899 (Araneae: Theraphosidae), a Western Ghats endemic ground mygalomorph. Journal of Threatened Taxa 1(6): 331-339.

Copyright: @ Manju Siliwal \& Sanjay Molur 2009. Creative Commons Attribution 3.0 Unported License. JoTT allows unrestricted use of this article in any medium for nonprofit purposes, reproduction and distribution by providing adequate credit to the authors and the source of publication.

Author Details: See end of article.

Author contributions: See end of article.

Acknowledgements: We are thankful to Ms. Sally Walker, Zoo Outreach Organisation, for her encouragement and constant support to lesser-known fauna and flora conservation and research; to The Rufford Maurice Laing Foundation for financial support to the Indian Tarantula project, during the survey trip of which this spider was located; to Oregon Zoo for funding the Uttara Kannada study; to Mr. Varad Giri for collecting specimens from Amboli; to Ms. Payal Molur for helping SM in field surveys; and to Prof. M. Ganeshkumar Forest College and Research Institute, Mettupalayam, Tamil Nadu, for providing technical help.
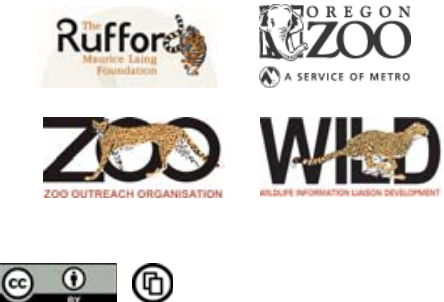

OPEN ACGESS | FREE DOWNLOAD
Abstract: The genus Thrigmopoeus is endemic to the Western Ghats of India, and is so far represented by two species: Thrigmopoeus truculentus Pocock, 1899 and T. insignis Pocock, 1899. The distribution of $T$. truculentus was considered to be restricted to its type locality until a few populations were identified in other places. In this paper we provide detail morphometry and characters used in modern-day taxonomy to redescribe the female of $T$. truculentus, with additional notes on its distribution, range extension, burrow and habitat.

Keywords: Mygalomorph, range extension, redescription, taxonomy, Theraphosidae, Thrigmopoeus truculentus

Abbreviations: AME - Anterior Median Eye; d - dorsal; fe - femur; PME - Posterior median eye; ALE - Anterior lateral eye; me - metatarsus; MOQ - Median ocular quadrate; $p$ - prolateral; pa patella; PLE - Posterior lateral eye; PLS - Posterior lateral spinnerets; PMS - Posterior median spinnerets; $r$ - retrolateral; ta - tarsus; ti - tibia; v - ventral; WILD - Wildlife Information Liaison Development Society.

\section{INTRODUCTION}

The family Theraphosidae of the suborder Mygalomorpha is formally represented by 53 species under 11 genera in India (Platnick 2009) - 10 genera of ground dwelling/ burrowing spiders and one arboreal genus. The ground burrowers are more common than the arboreal spiders, with some genera represented more commonly than others (Molur \& Siliwal 2004). The genus Thrigmopoeus is known from two described species. The valid species of this genus are Thrigmopoeus insignis Pocock, 1899 and T. truculentus Pocock, 1899, both described from the northern Western Ghats (north of Palghat gap) in Karnataka State; the type species of T. insignis was described from Kanara Ghats, while T. truculentus was described from Karwar. The description of these species is based on female specimens. A third species, T. minor was provisionally described by Strand (1907) under T. truculentus based on a male specimen collected from Mercara in Curg (=Madikeri in Coorg, Karnataka). Due to a lack of original description/literature (Pocock 1900) and the absence of female specimens from Madikeri, Strand (1907) could not compare the male specimen with the described species (T. truculentus, T. insignis) and therefore, provided it a provisional name T. minor. Later, Roewer (1943) synonymised $T$. minor with $T$. truculentus until further work could prove its the validity as a species. We collected female specimens of Thrigmopeous from Madikeri, which is the type locality of T. minor, and on examining the specimen it was confirmed as T. truculentus. During our surveys in Coorg and nearby areas only one species of Thrigmopoeus (T. truculentus) was found. Therefore, in this paper we confirm the junior synonymy of $T$. minor with $T$. truculentus. We also confirm the range extension of $T$. truculentus. Until recently, it was assumed that the species had a very restricted distribution, but records of Strand (1907) and recent collections point to a wider distribution of T. truculentus.

Pocock's (1899) description of the genus Thrigmopoeus and the two species (T. truculentus and T. insignis) provided a basic understanding. However, given the advances that have taken place in species descriptions, it is appropriate to redescribe the species based on the current standard format. Based on the descriptions by Pococok (1899), we were able to identify the specimens collected from different localities as belonging to T. truculentus. We therefore take the opportunity to redescribe the female of $T$. truculentus from fresh collections from the wild following Raven (2005). 


\section{Genus Thrigmopoeus Pocock, 1899}

Diagnosis: Fovea slightly procurved; this genus differs from the genus Haploclastus by having cluster of long, curved, pointed setae on retrolateral face of chelicerae and a horizontal band of small pointed setae arranged randomly and below suture two curved vertical bands of small and long setae in the center and towards inner side on prolateral face of maxillae. Spines present on dorsal and ventral side of Leg III and IV (Pocock 1899).

\section{Distribution: India}

Taxonomy: Thrigmopoeus truculentus Pocock, 1899

Type material: Holotype, female, Karwar, Karnataka, coll. Bombay Natural History Society, deposited at Museum of Natural History, London, registration number not available.

Material examined: 1 female, 3.i.2006, Madikeri $\left(12^{\circ} 24^{\prime} 45.1^{\prime \prime} \mathrm{N} \& 75^{\circ} 34^{\prime} 39.2^{\prime \prime} \mathrm{E}\right.$; $997 \mathrm{~m})$, Coorg, Karnataka, coll. Sanjay Molur and Payal Molur, WILD-05-ARA137; 1 female, 27.vii.2002, Amboli (15 $\left.57^{\prime} 37^{\prime \prime N} \& 73^{\circ} 59^{\prime} 58^{\prime \prime} \mathrm{E} ; 750 \mathrm{~m}\right)$, Sindhudurg District, Maharashtra, coll. Varad Giri, WILD-05-ARA-139.

Diagnosis: Body colour brown. It differs from $T$. insignis by having fovea smaller than ocular width, two black bands emerging from fovea running on the sides of caput (prominent in fresh specimen), small black spinules present on cephalothorax. Inferior claw present on Leg IV, paired claws without any teeth on all the legs and single bare claw on palp. Spermathecae simple, two hillockshaped lobes.

Female from Madikeri (Images 1-20, Figure 1-8)

Description (measurements in $\mathbf{m m}$ ): Carapace 13.86 long, 10.96 wide, chelicerae 5.42 long intact, 9.94 long after dissection. Sternum 7.96 long, 5.18 wide. Abdomen 15.34 long, 10.08 wide. Spinnerets: PMS, 1.8 long, 0.8 wide, 0.7 apart; PLS, 2.4 basal, 1.22 middle, 2.82 distal; midwidths $1.1, \quad 1.0, \quad 0.9$ respectively. Leg and palp morphometry given in Table 1 .

Carapace (Image 2; Fig. 1): Fovea slightly procurved, smaller than ocular

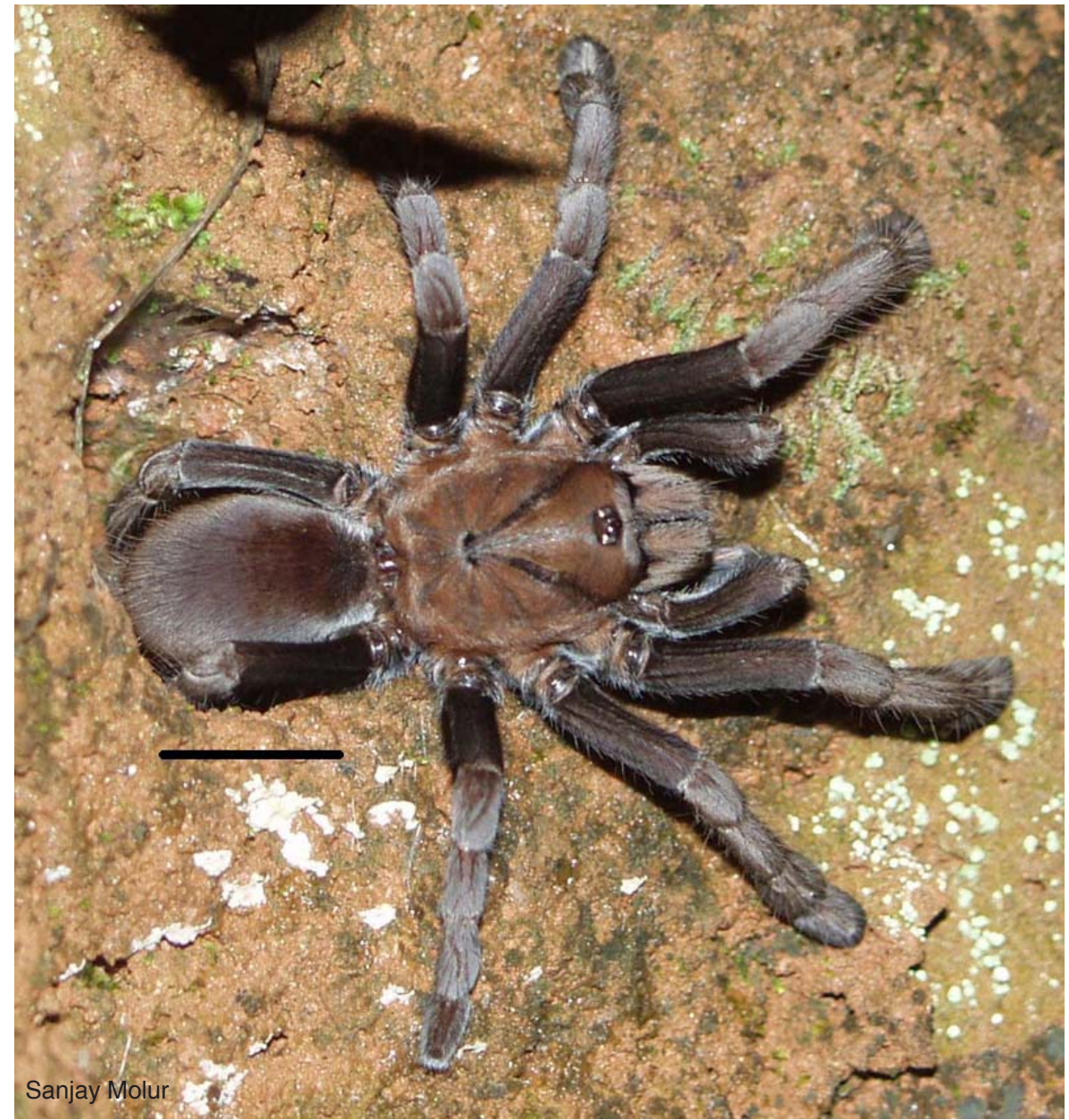

Image 1. Thrigmopoeus truculentus from Coorg. Scale $10.0 \mathrm{~mm}$

width, two black bands emerging from fovea and running on either side of caput in the shape of ' $\mathrm{V}$ ' (prominent in live spider), margins light black to brown (Images 1, 2). Length to width 1.26; uniform reddish-brown in alcohol, dry golden brown; cover of long golden wavy hairs and small black spinules (Image 3), more concentrated towards margins and along the intersternal ridges radiating from fovea; no setae.

Eyes (Image 4; Fig. 2): Ratio of group width to length 1.4. PLE smaller than ALE but perceptibly bigger than PME, ALE clearly larger than the rest. Eye diameter: ALE, 0.7; AME, 0.62; PLE, 0.55; PME, 0.19. Distance between the eyes: AME-AME, 0.19; PME-PLE, 0.1; ALE-PLE, 0.28; AME-ALE, 0.14; PME-PME, 1.17. Ocular Quadrate, 1.51 long, 2.7 wide. MOQ: length, 1.18; front width, 1.29; back width, 1.65 .

Maxilla (Images 5-7; Fig. 3): Posterior ventral edge gently rounded and long; retro-face yellowish-red, smooth, glabrous (Image 8). Cuspules: ca 200 in anterior corner in roughly traingular region. Posterior edge almost straight, concave near heel.

Maxillary lyra (Image 9; Fig. 4): No definite shape, ca. 0.54 of mid-maxilla length; small pointed thorn setae above suture arranged randomly, below suture pointed setae arranged in two vertical bands, center to inner point: center band, narrow, only small pointed thorn setae arranged in 3-4 in a row, gaps evenly spaced and broad; inner point band, small and long pointed setae randomly spaced. Thin long setae on the ventral edge. No ventral brush of lyra.

Labium (Image 6; Fig. 5): Over 100 cuspules in band for one-fourths of anterior length; cuspules ca. similar in size to maxillary. Basal groove shallow, distinct. Labiosternal groove concave. Collar like rise on sternum on lateral sides of the labiosternal groove.

Chelicera (Images 10-13; Fig. 6-7): Intercheliceral spines absent. Ectal lyrate 


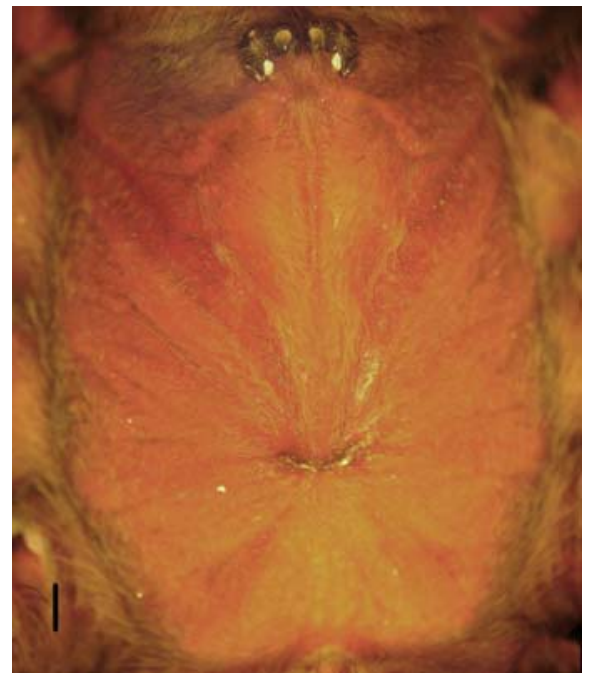

Image 2. Cephalothorax. Scale $1.0 \mathrm{~mm}$

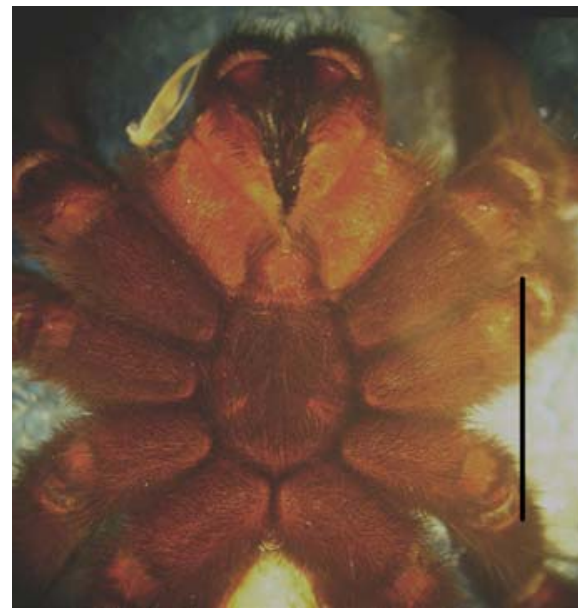

Image 5. Sternum, coxa, maxillae, labium. Scale $10.0 \mathrm{~mm}$

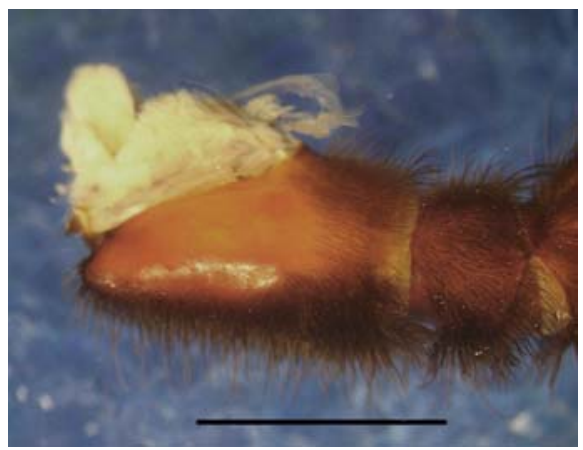

Image 8. Maxillae, retrolateral face. Scale $5.0 \mathrm{~mm}$

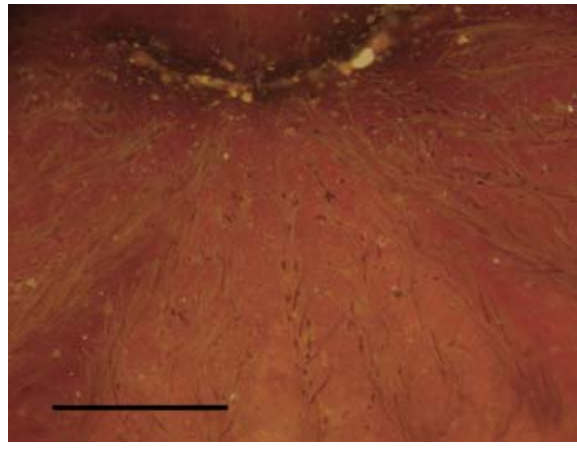

Image 3. Spinules on cephalothorax. Scale $1.0 \mathrm{~mm}$

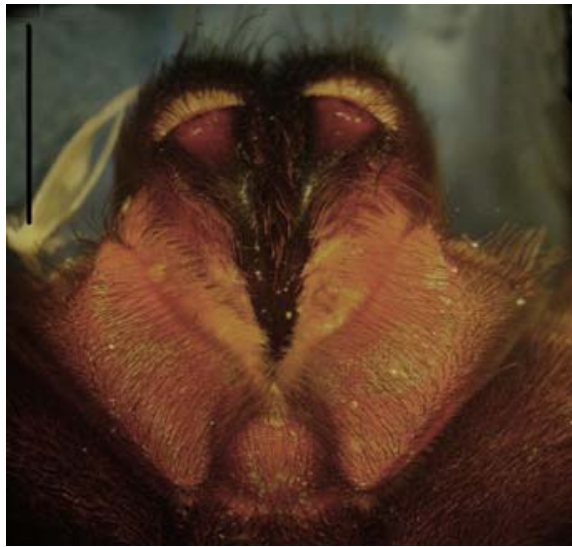

Image 6. Labium and Maxillae. Scale $5.0 \mathrm{~mm}$

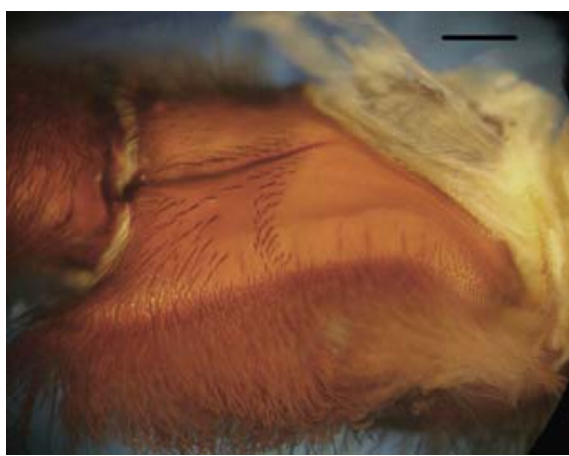

Image 9. Maxillary lyra, prolateral face. Scale $1.0 \mathrm{~mm}$

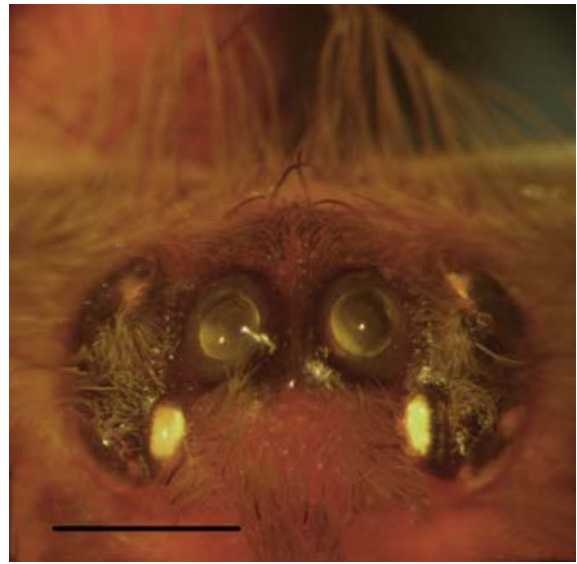

Image 4. Eyes. Scale 1.0mm

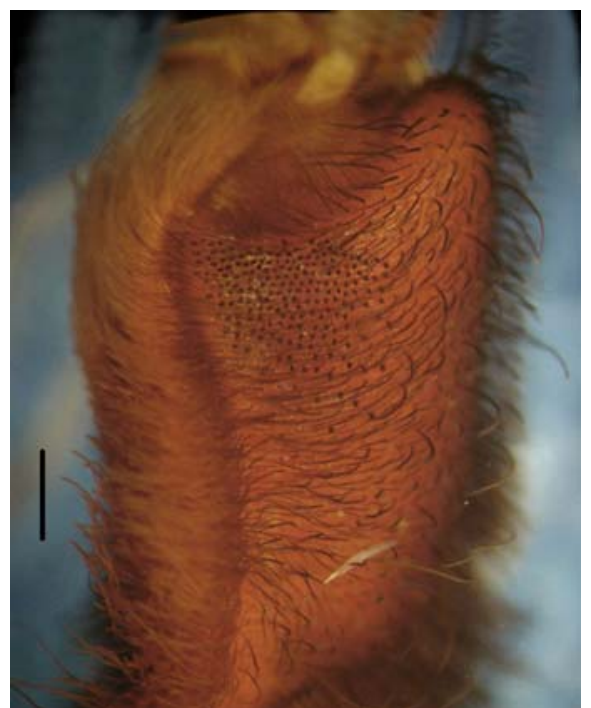

Image 7. Cuspules on maxillae. Scale $1.0 \mathrm{~mm}$

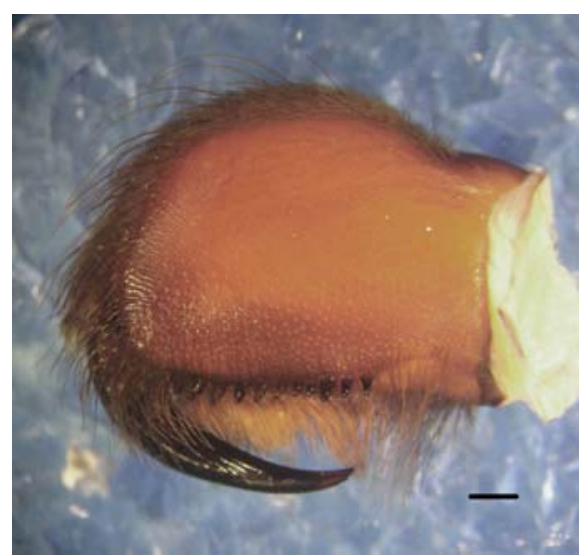

Image 10. Chelicerae, prolateral face. Scale $1.0 \mathrm{~mm}$ 


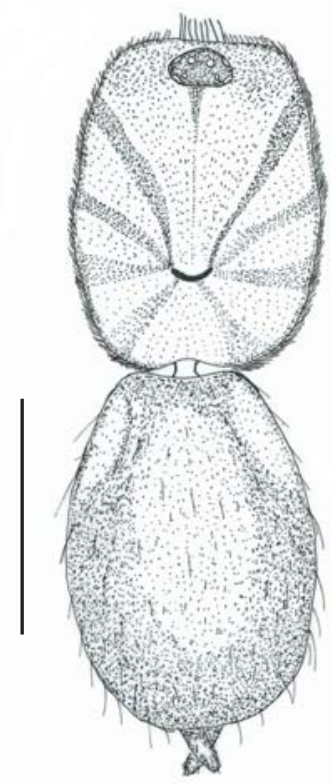

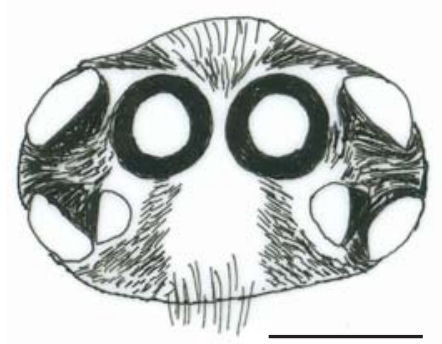

Figure 2. Eyes. Scale $1.0 \mathrm{~mm}$

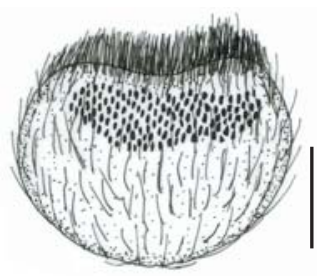

Figure 5. Labium.

Scale $1.0 \mathrm{~mm}$

Figure 1. Cephalothorax and abdomen. Scale $10.0 \mathrm{~mm}$

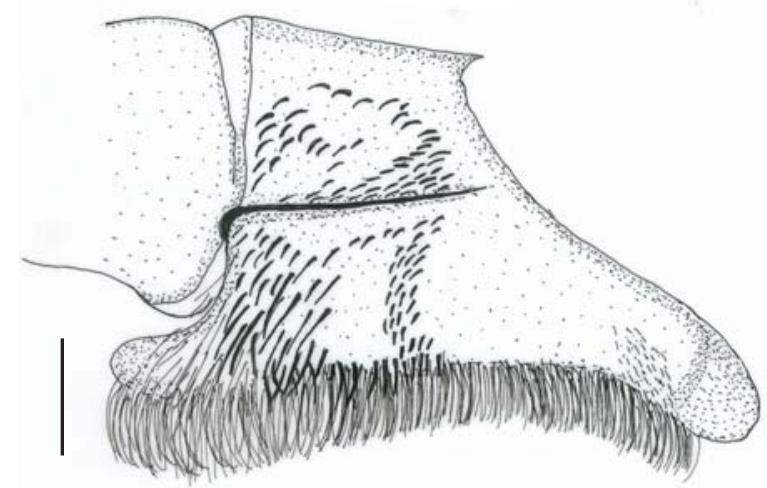

Figure 4. Maxillary lyra. Scale $1.0 \mathrm{~mm}$
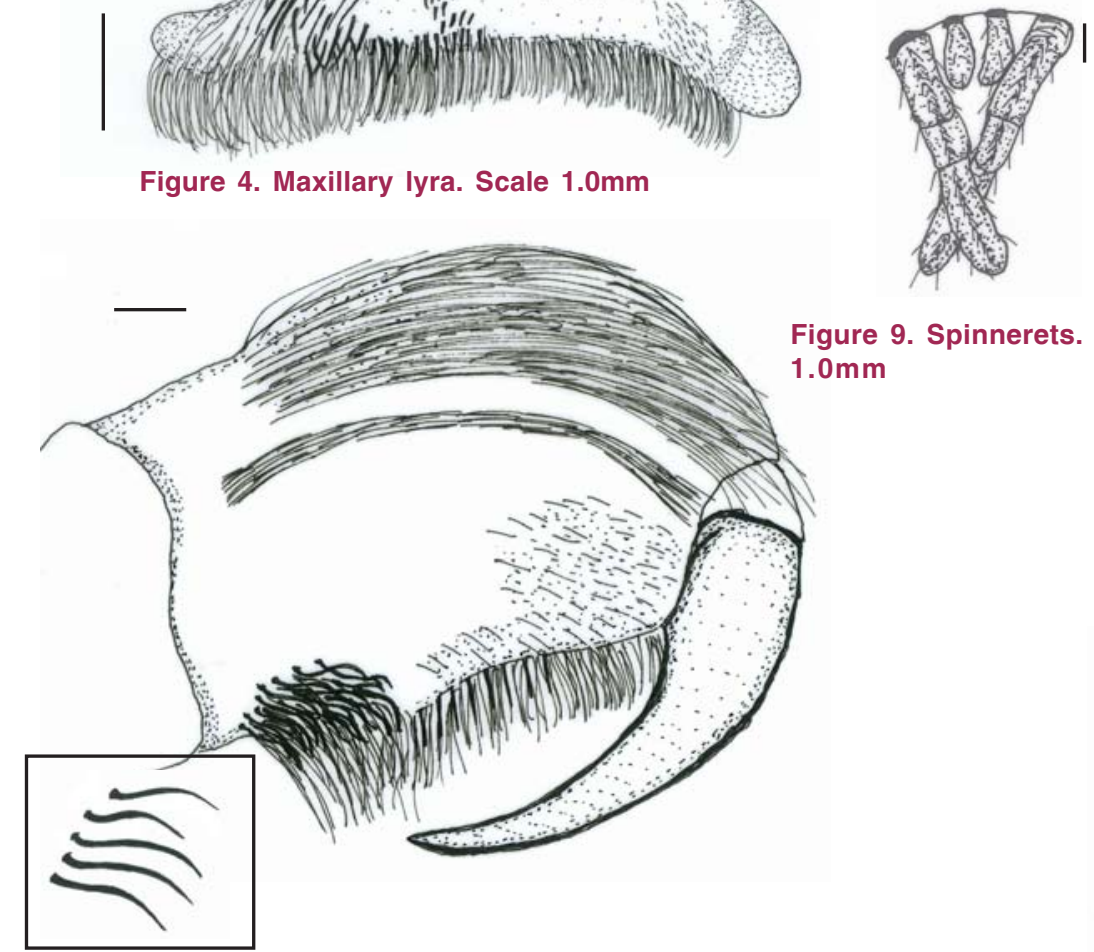

Figure 9. Spinnerets. Scale $1.0 \mathrm{~mm}$

Figure 7. Chelicerae, retrolateral face. Inset, Chelicerae lyra setae. Scale $1.0 \mathrm{~mm}$

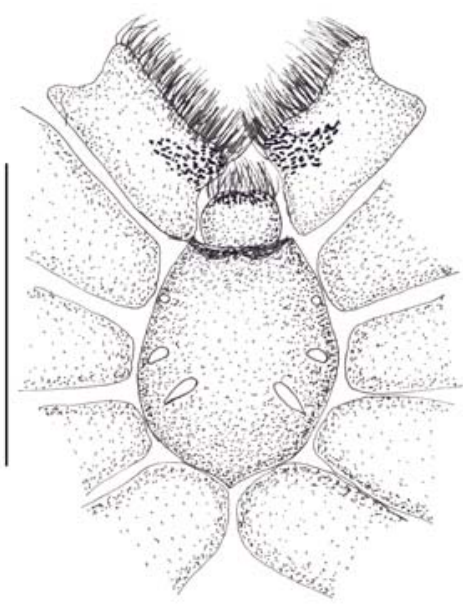

Figure 8. Sternum. Scale $10.0 \mathrm{~mm}$

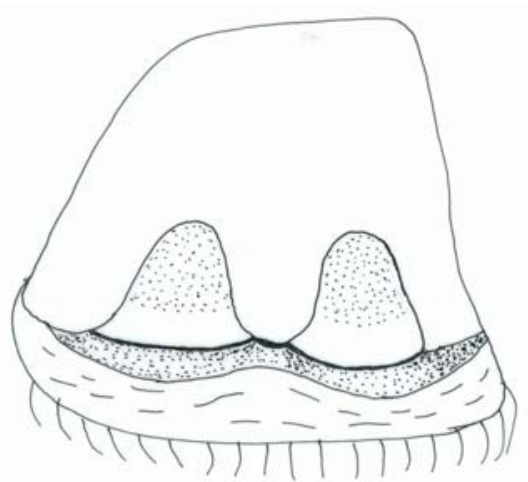

Figure 10. Spermathecae. Scale $1.0 \mathrm{~mm}$ 
Table 1. Morphometry of legs and palp of Thrigmopoeus truculentus Pocock, 1899, WILD-06-ARA-137 (137), WILD-06-ARA139 (139) (measurements in $\mathrm{mm}$ ):

\begin{tabular}{|c|c|c|c|c|c|c|c|c|c|c|}
\hline \multirow[t]{2}{*}{ Leg parts } & \multicolumn{2}{|l|}{ I } & \multicolumn{2}{|c|}{ II } & \multicolumn{2}{|c|}{ III } & \multicolumn{2}{|c|}{ IV } & \multicolumn{2}{|c|}{ Palp } \\
\hline & 137 & 139 & 137 & 139 & 137 & 139 & 137 & 139 & 137 & 139 \\
\hline Femur & 11.58 & 13.54 & 9.74 & 10.3 & 9.02 & 9.20 & 10.76 & 11.90 & 8.94 & 9.72 \\
\hline Patella & 7.12 & 7.68 & 6.02 & 6.86 & 5.42 & 5.92 & 6.42 & 6.56 & 5.00 & 5.94 \\
\hline Tibia & 9.00 & 11.00 & 8.96 & 9.00 & 5.84 & 6.64 & 9.3 & 10.4 & 6.76 & 6.98 \\
\hline Metatarsus & 7.98 & 8.78 & 6.52 & 7.74 & 6.18 & 7.00 & 9.44 & 10.24 & - & - \\
\hline Tarsus & 6.48 & 7.32 & 5.3 & 6.48 & 4.8 & 5.38 & 5.1 & 6.12 & 7.0 & 7.40 \\
\hline $\begin{array}{l}\text { Total } \\
\text { Midwidth }\end{array}$ & 42.16 & 48.32 & 36.54 & 40.38 & 31.26 & 34.14 & 41.02 & 45.22 & 27.7 & 30.04 \\
\hline Femur & 2.4 & 3.10 & 2.22 & 2.70 & 2.7 & 2.80 & 2.4 & 2.78 & 2.38 & 2.22 \\
\hline Tibia & 2.3 & 2.62 & 2.0 & 2.34 & 2.2 & 2.34 & 2.0 & 2.16 & 2.72 & 2.58 \\
\hline
\end{tabular}

area, groove glabrous; lyra setae, long curved thorn setae in 45 curved (parallel) lines. Prolateral teeth 11, many small granules at basal chelicerae furrow or groove.

Sternum (Image 5; Fig. 8): Longer than wide, high in centre, slopping gradually, covered with long, dense, black hair. Posterior edge pointed but not separating coxae IV. Prostate hair mat strong, dense, black hairs. Marginal thorns absent. Pedicel not clearly seen.

Sigilla (Image 5; Fig. 8): 3 pairs, posterior 1.0 diameter, ca. 2.5 lengths apart; only 1 length from margin; middle about half size of posterior; within 1 length of margin; anterior very small, marginal.

Legs: 1423. Leg I clearly thicker than IV, II subequal to IV. Basifemoral thorns absent on all. Femora I-II prolaterally with long bushy fine hairs; III distinctly incrassate. Metatarsus IV 1.8 times longer than tarsus, rest slightly longer than tarsae.

Leg pilosity: (number of long hairs extending well above base layer). Tibia I $\mathrm{p}=8-10, \mathrm{~d}=5-10, \mathrm{r}=7-10, \mathrm{v}-6$; metatarsus I $\mathrm{p} 5-7, \mathrm{~d}=5-6, \mathrm{r}=2-4, \mathrm{v}=2-3$; tibia II $\mathrm{p}=5-7, \mathrm{~d}=3-5, \mathrm{r}=5-8$; metatarsus II v=2-3; tibia III v $=5-10$; metatasus III v=3-5; tibia IV $\mathrm{p}=30-35, \mathrm{~d}=20-25, \mathrm{r}=30-35, \mathrm{v}=10-15$; metatarsus IV $\mathrm{p}=\mathrm{r}=20-25, \mathrm{~d}=7-10, \mathrm{v}=2-3$; tarsus IV ca. 30-35 dorsolaterally on each side.

Trichobothria (Image 14): On tarsi basal filiform field slightly wider than clavate field and merges smoothly; clavates on tarsi I only in distal 2/3; long filiforms only in basal half but very few seen in the distal region, shorter filiforms intermixed with clavates distally. Clavate extent on II-IV cf. I in distal 2/3; long filiforms only in basal half, shorter filforms for length. Short epitrichobothrial hair field on I as wide as clavates and uniform height for length.

Leg coxae (Image 5): No thorns prolaterodorsally or retrodorsally. Coxal bases dorsally easily seen from above (Image.1). I longest, about 1.2 times length of II; IV clearly widest but longer than III and basally with anterior corner indistinct, edge curves dorsally, rounded at interface. Coxae, III sloping forward, III-IV sloping backward, ventrally with short, weak thorns only on prolateral faces of I-II, III-IV consist of hairs. I-IV ventrally with thick mat of black hair with few pallid hairs.

Retrolateral setation: Legs I-III with median narrow light brush, IV glabrous; III-IV with setose mound up from inner corner low mound with few bristles. All retrolaterally lack ventral ledge and ventrally with uniform setation.

Scopulae: Entire, dense on tarsi I-III and metatarsi I-II; tarsi II entire, long hair in the center but not divided; on tarsi II entire divided at base with few long hairs; on metatarsi III for $2 / 3$ of length, not divided; on metatarsi IV for $1 / 2$ of length, divided by setal band 3-4 wide. Scopula well developed on ventrolateral tarsus I-II. No scopula on proventral tibiae I-II.

Spines, metatarsi: I, O; II, 1 distal ventral; III-IV, 1 distal ventral, 2 distal ventrolateral, 1 distal dorsal; elsewhere absent.

Claws (Images 16-18): Third claw only on IV, distinct hooked. Paired claws on all legs without dentition, and single bare claw on palp.

Abdomen pilosity (Image 2): Cuticle not exposed dorsally and ventrally; dorsally covered with fine layer of brown long hair and bristles, many pallid; ventrally black with fine layer of many long black hair bristles.

Spinnerets (Image 19; Fig. 9): 2 pairs, yellowish-orange, covered with black hair.

Spermethecae (Image 20; Fig. 10): Hillock shaped, consist of a pair of large lobes, broader at base and gradually narrowing towards apex with a smooth curve at distal end.

\section{Morphometry of specimen from Amboli, Maharashtra (Images 21, 23)}

Description (measurements in $\mathbf{m m}$ ): Female, total length 32.14. Carapace 15.5 long, 12.86 wide, chelicerae 6.68 long intact, 9.42 long after dissection. Sternum: 7.88 long, 6.78 wide; sigilla, three, posterior 2.6 length apart, middle 4.5 part apart, anterior, round marginal. Metaspines: Leg I, absent; Leg II, 3 small, 1 ventrodistal, 2 ventrolateral, on left leg only 1 small ventrodistal; Leg III and IV, total 4 large, one dorsodistal, 2 ventrolateral, 1 ventrodistal. Abdomen 16.64 long, 8.24 wide. Spinnerets: PMS, 1.82 long, 1.32 wide, 1.0 apart. PLS, length: 2.64 basal, 1.58 middle, 3.02 distal; midwidths $1.46,1.12$, 1.0 respectively. Leg morphometry is given in Table 1.

Eye diameter: ALE, 0.82; AME, 0.72; PLE, 0.55; PME, 0.35. Distance between the eyes: AME-AME, 0.11; PME-PLE, 0.23; ALE-PLE, 0.3; AME-ALE, 0.29; PME-PME, 1.47. Ocular Quadrate, 1.35 long, 3.01 wide. MOQ: length, 1.12; front width, 1.55; back width, 1.95 .

Other morphological characters same as the Coorg specimen.

Remarks: This species could be distinguished from Thrigmopoeus insignis by having brown body colour and comparatively smaller in size; fovea less than ocular width; Leg I more than three times longer than cephalothorax length; presence of dorsal and ventral metaspines on leg III-IV.

Burrow (Image 22): All the burrows of this species were seen on slopes of bunds usually under tree shade. The burrow entrance of the examined specimen WILD-ARA-137 from 


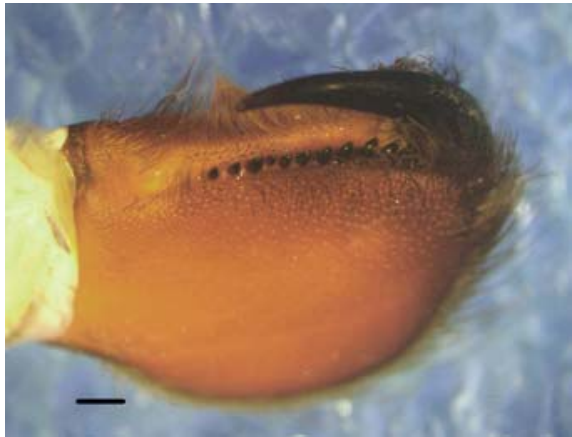

Image 11. Chelicerae teeth. Scale $1.0 \mathrm{~mm}$

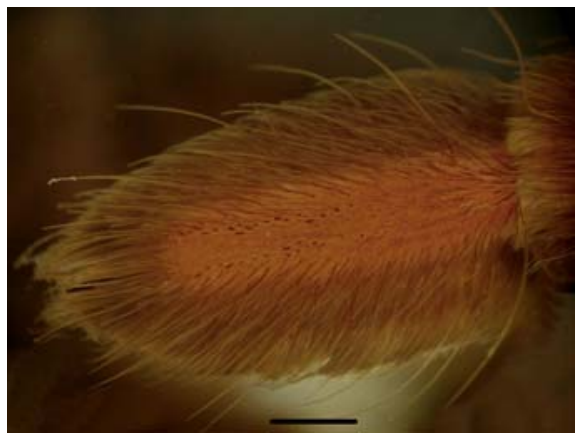

Image 14. Trichobothria on Tarsus III. Scale $1.0 \mathrm{~mm}$

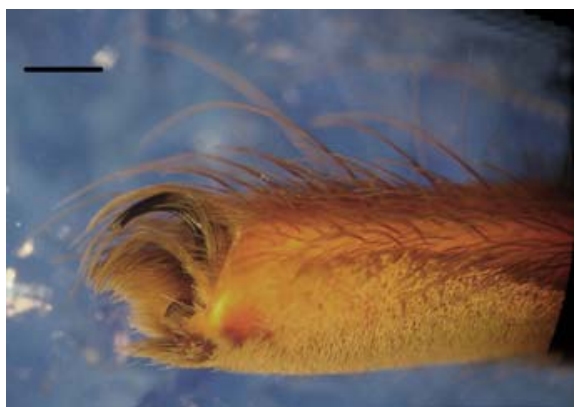

Image 17. Inferior claw on Tarsus IV. Scale 1

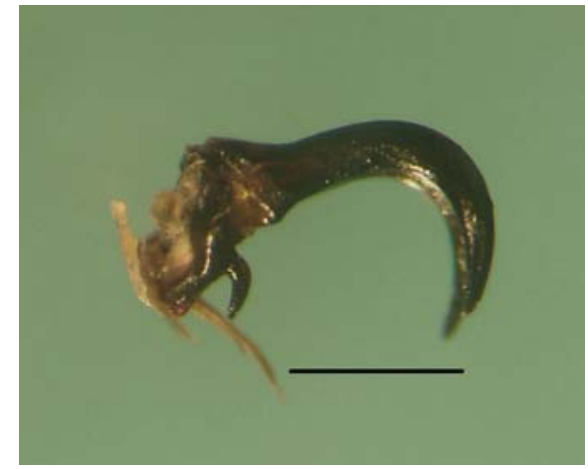

Image 18. Claw IV. Scale 1.0mm

Image 15. Tarsus IV, Cracked tarsi. Scale $1.0 \mathrm{~mm}$

Image 12. Chelicerae, retrolateral face.

Scale $1.0 \mathrm{~mm}$
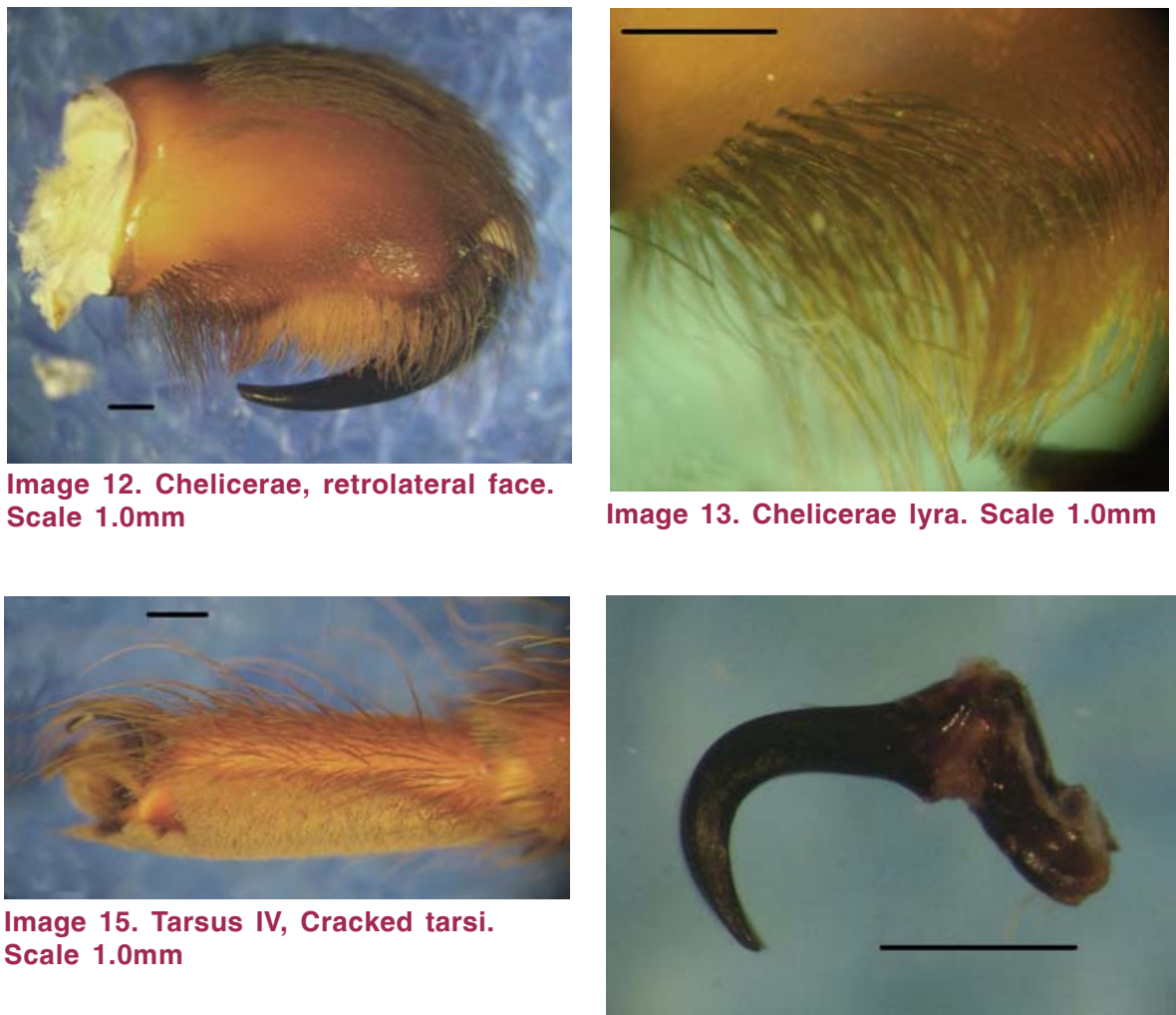

Image 16. Claw I. Scale $1.0 \mathrm{~mm}$

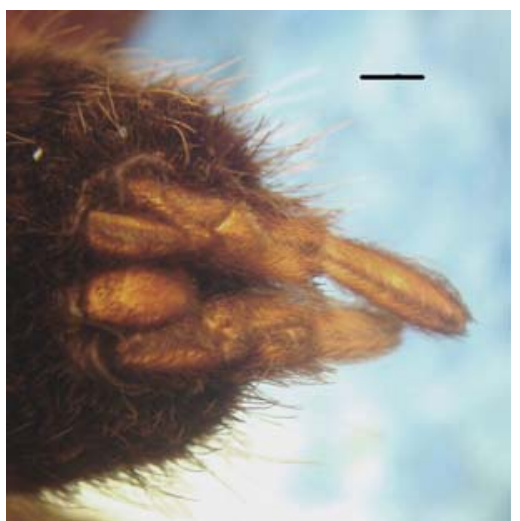

Image 19. Spinnerets. Scale $1.0 \mathrm{~mm}$

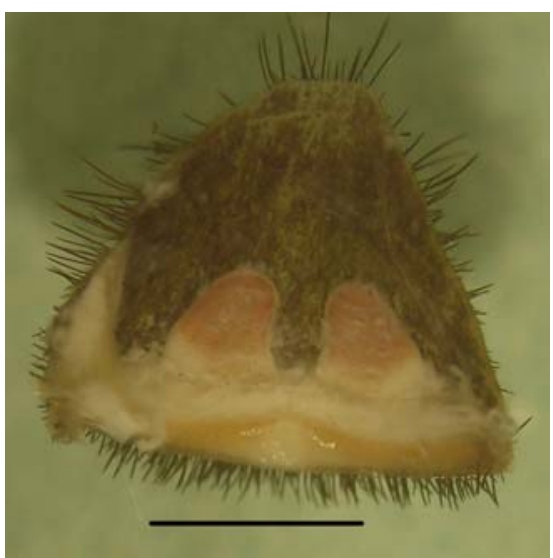

Image 21. Spermetheca of WILD-139. Scale $1.0 \mathrm{~mm}$

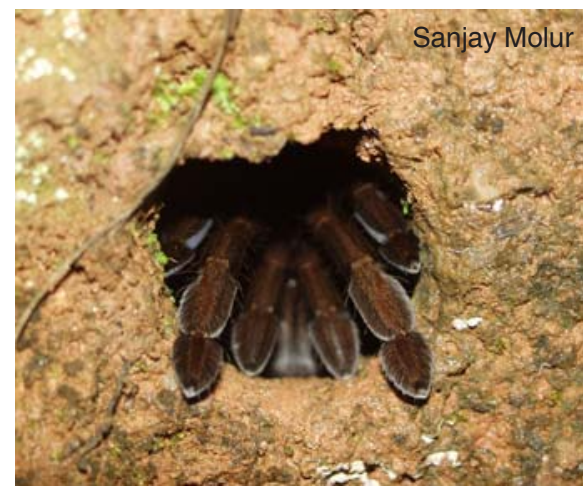

Image 22. Typical burrow-stance of Thrigmopoeus truculentus
Image 20. Spermetheca of WILD-137. Scale $1.0 \mathrm{~mm}$ 


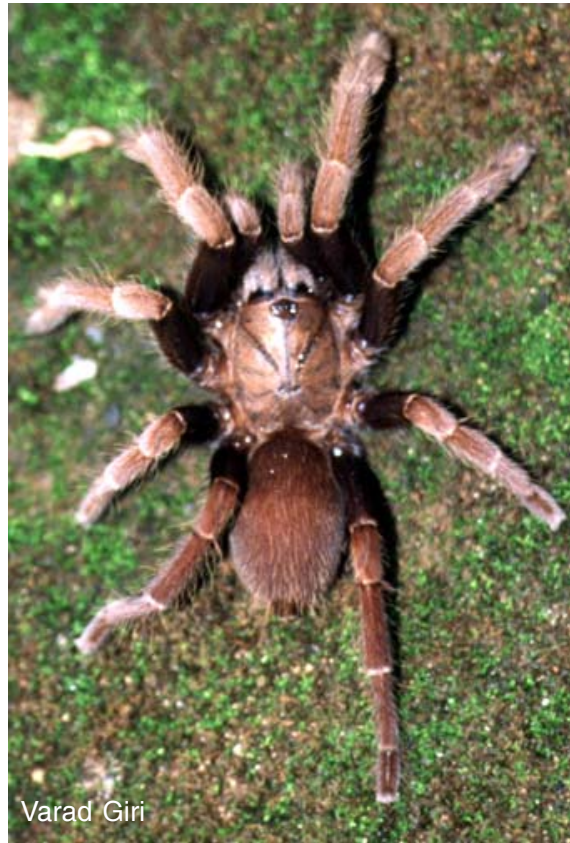

Image 23. Thrigmopoeus truculentus from Amboli, Maharashtra

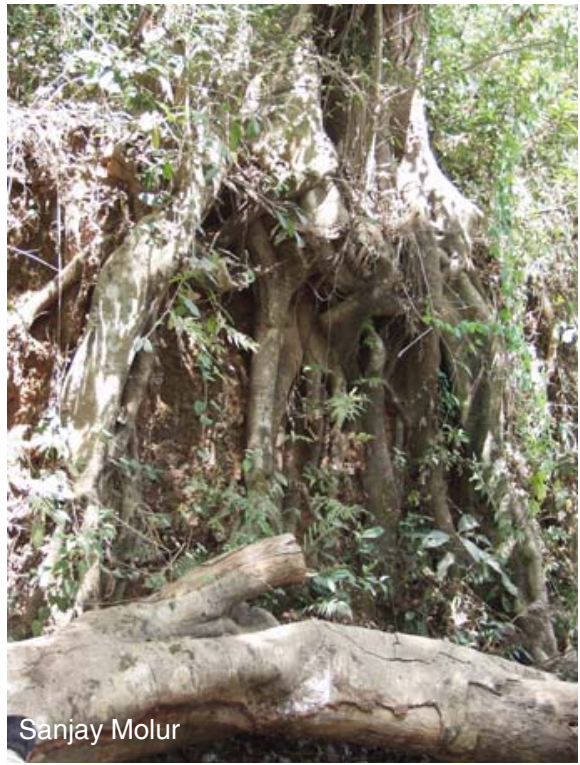

Image 24. Habitat of Thrigmopoeus truculentus - below large tree on the mud bund

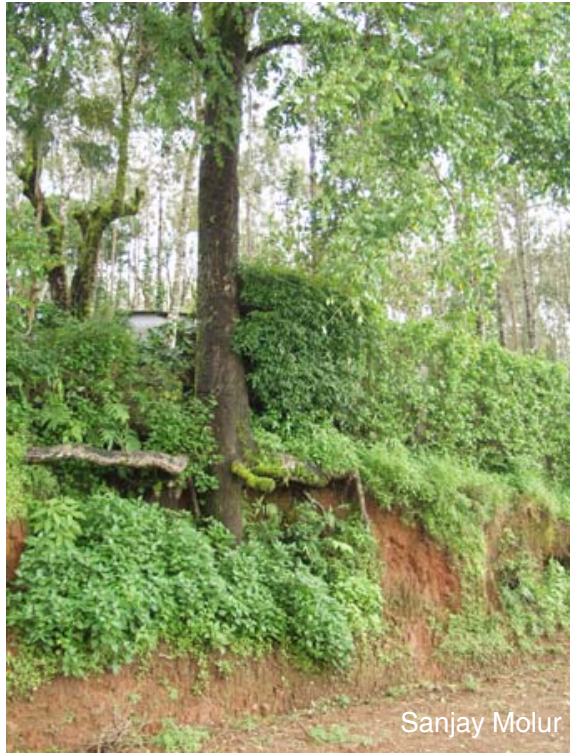

Image 25. Habitat of Thrigmopoeus truculentus - Road side mud-bunds
Coorg was a simple circular/round opening without any turret, about $3.7 \mathrm{~cm}$ diameter and $27.5 \mathrm{~cm}$ deep, sloping downwards and ending in a wide chamber/bulb. A small additional chamber was observed just above the brooding chamber, which could be the feeding/escape chamber. The burrow was completely lined with silk.

\section{Habitat (Images 24, 25)}

Burrows of these spiders were observed at $0.5-5 \mathrm{~m}$ height from the ground on road side mud bunds in Coorg and Uttara Kannada districts. These bunds are usually covered with ferns and grasses in monsoon and post monsoon. The spiders were found on road-side bunds usually at the base of trees in between the tangles of roots. The burrows were found on bunds with high canopy or in ghat areas where direct sunlight was minimum or nil. Very few sightings of these burrows were on bunds with no canopy. In most cases, the trees over the bunds were cut or lopped for road maintenance. In Castle Rock, there were two sites where a stretch of ghat of $50 \mathrm{~m}$ and $200 \mathrm{~m}$ length respectively and height of $5-6 \mathrm{~m}$ on either side of road was cut These areas had very less light penetration during the day giving an effect of $80-100 \%$ canopy cover, partially due to the height of bunds and mainly due to vegetation (trees and shrubs). A microclimate with high humidity (70-80\%) and temperature ranging from 22 to $30^{\circ} \mathrm{C}$ during day time in this area seems to be the ideal habitat for ground theraphosids. Due to favourable habitat conditions the congregation of ground burrowing theraphosid spiders was very high (323 burrows in 200m). The lone Amboli specimen was found on a bund in the semievergreen forest in an unprotected area frequented by humans for tourism (Varad Giri, pers. comm., 13 March 2007). The Agumbe specimen was sighted in an undisturbed evergreen forest (Binu Arthur, pers. comm., August 2005). In Uttara Kannada and Goa T. truculentus was commonly found sharing habitat with another ground theraphosid, Chilobrachys fimbriatus. In Castle Rock and Anshi NP/WLS, T. truculentus was found sharing habitat with T. insignis.

\section{Distribution}

India- Karnataka: Karwar; Anshi NP (15⒈ $8^{\prime} 40.2^{\prime \prime} \mathrm{N} \&$ $\left.74^{\circ} 18^{\prime} 50.2^{\prime \prime} \mathrm{E}, 559 \mathrm{~m}\right)$, Castle Rock (15 $244^{\prime} 49.4^{\prime \prime} \mathrm{N} \&$ $\left.74^{\circ} 19^{\prime} 37.5^{\prime \prime} \mathrm{E}, 620 \mathrm{~m}\right)$ in Uttara Kannada District; Madikeri, Abbe falls, Galibeedu, Virajpet-Makutta road and near Talakaveri in Coorg District; and Agumbe in Shimoga District. Goa: Mollem WLS (15 $\left.5^{\circ} 1^{\prime} 34.4^{\prime \prime N} \& 74^{\circ} 15^{\prime} 12.0^{\prime \prime} \mathrm{E}, 112 \mathrm{~m}\right)$ in North Goa District. Maharashtra: Amboli in Sindhudurg District. Thrigmopoeus truculentus is endemic to the northern Western Ghats of Karnataka, Goa and southern Maharashtra. Specifically, the species has been recorded from vertical bunds along roads and trek paths in Coorg as well as other locations in Karnataka, Goa and Maharashtra. The animal has not been recorded from Karwar district after its first description. But during our recent surveys, this species was recorded from Anshi WLS (approximately, 60km from Karwar) and Castle Rock and it suggests that the species is well distributed throughout Uttara Kannada District including Karwar. The species occurs at an altitudinal range of 90 to $1000 \mathrm{~m}$, and occupies a range of approximately $25,000 \mathrm{~km}^{2}$. Considering its patchy distribution and affinity to relatively undisturbed areas with bunds, the area of occupancy could be less than $10 \%$ of the extent of occurrence (Image 26).

In three instances in Coorg, a single adult female was spotted in each location, of which detailed observations over a period of three years was conducted on one spider (called Abbe) (20042006), while the other one (called Galibeedu) was studied over four months (October 2005- January 2006). All three individuals were observed in burrows on road-side bunds. In each case, the bund extending about $600-800 \mathrm{~m}$ on one side of the road had only one adult female. In the case of Abbe, the adult female was observed to have two litters each year (August and January-February), and in one season (February 2006), we observed seven additional burrows close to the adult burrow. 


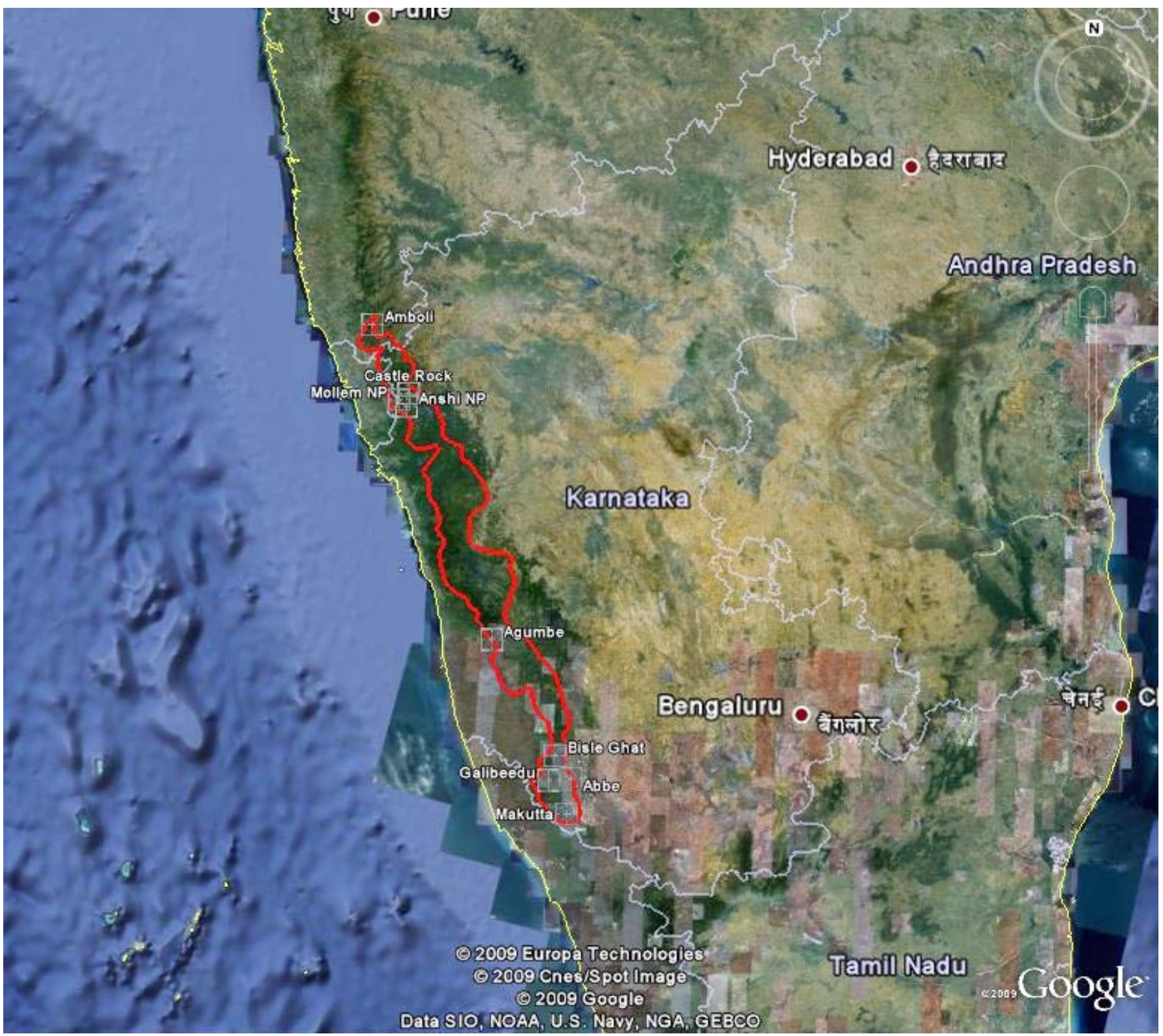

Image 26. Distribution of Thrigmopoeus truculentus Pocock, 1899 in the Western Ghats. Locations indicated are confirmed sightings. The polygon is drawn according to habitat characteristics of observed localities. Courtesy Google Earth.

Each of the additional burrows had a juvenile spider from the previous litter (August 2005), while the female had another litter residing in the burrow in February 2006. In the case of ground spiders, it is estimated that spiderlings often undergo two moults within the mother's burrow before moving out. The seven juveniles from the previous clutch that had established burrows, however, were missing subsequently in April-May 2006. This could be due to several reasons - predation, migration and impact of bund clearance by municipality workers. In the last three years we have observed the single adult female Abbe to have moved her burrow four times in a radius of $0.3 \mathrm{~m}$ from the original burrow observed in 2004, each time the area of her previous burrow destroyed from bund maintenance. The recruitment to the population of the Karwar Large Burrower in Abbe and Galibeedu has been zero over the last three years.

Status: The spider is threatened by several factors, which include severe fragmentation, habitat degradation, soil erosion, developmental activities, and trade. The causes for habitat degradation are due to road widening, cutting of trees, bund maintenance, soil erosion and other kinds of human interference such as tourism (Sanjay Molur, Manju Siliwal, Varad Giri, pers. obs.). It is assumed that the area of spider habitat has decreased over the years. Based on the estimated extent of occurrence $\left(25,000 \mathrm{~km}^{2}\right)$ this species barely misses the Vulnerable category as listed in the 2008 IUCN Red List of Threatened Species (Molur et al. 2008). However, due to the continuing decline inferred in its area of occupancy, in the quality of habitat, and in the population, this species qualifies for Near Threatened category.

\section{References}

Molur, S. \& M. Siliwal (2004). Common names of South Asian 
theraphosid spiders (Araneae: Theraphosidae). Zoos' Print Journal 19(10): 1657-1662.

Molur, S., M. Siliwal \& B.A. Daniel (2008). Thrigmopoeus truculentus. In: IUCN 2009. IUCN Red List of Threatened Species. Version 2009.1. <www.iucnredlist.org>. Downloaded on 13 June 2009.

Platnick, N.I. (2009). The world spider catalog, version 9.5. American Museum of Natural History, online at http://research.amnh.org/entomology/spiders/catalog/index.html (accessed on 15 March 2009).

Pocock, R.I. (1899). Diagnoses of some new Indian Arachnida. Journal of the Bombay Natural History Society 12: 744-753.

Raven, R.J. (2005). A new tarantula species from northern Australia (Araneae, Theraphosidae) Zootaxa 1004: 15-28.

Strand, E. (1907). Aviculariidae und Atypidae des Kgl. Naturalienkabinetts in Stuttgart. Jahresh Ver. Naturk. Württbg 63: 1-100.
Author Details: MANJU SILIWAL is a research associate at Wildlife Information Liaison Development Society, Coimbatore, currently working as an arachnologist. She has been working on ecology and taxonomy of mygalomorph spiders of India. She is in the process of describing new species of spiders including trapdoor spiders and tarantulas. SANJAY MOLUR is the founder secretary of WILD and executive director of ZOO. He is currently involved in studies on rodents and bats in Coorg. $\mathrm{He}$ is also involved in trade and ecological studies of mygalomorph spiders in India since 2000.

Author contribution: MS carried out surveys in Uttara Kannada and Coorg districts for tarantula spiders and SM carried out monitoring of tarantulas in Coorg. Identification and description of the species in this paper is done by MS with help from SM. The paper is written by both MS and SM. 